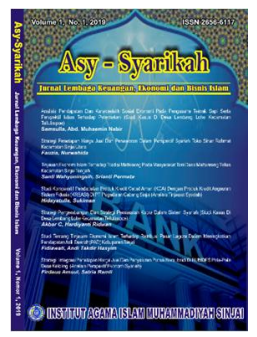

Asy-Syarikah

Jurnall Lembaga Keuangan, Ekonomi dan Bisnis Islam

Volume 3, No. 1, 2021

ISSN (print) : 2656-6117

ISSN (online) : 2715-0356

Homepage : http://journal.iaimsinjai.ac.id/index.php/asy-syarikah

\title{
PELAKSANAAN CORPORATE SOCIAL RESPONSIBILITY BNI SYARIAH DENGAN INDEKS ISLAMIC SOCIAL REPORTING
}

\author{
A. Rio Makkulau Wahyu ${ }^{1}$, Ariyanto ${ }^{2}$ \\ ${ }^{1}$ IAIN Parepare, Parepare \\ ${ }^{2}$ IAIN Parepare, Parepare \\ Korespondesi Penulis. E-mail: andiriom@gmail.com, Tlp: 085242130100
}

\begin{abstract}
Abstrak
Penelitian ini bertujuan untuk mengetahui apa yang dimaksud CSR menggunakan indeks ISR dan ntuk mengetahui pelaksanaan CSR pada BNI Syariah sesuai dengan indeks ISR. Penelitian ini merupakan penelitian berjenis kuantitatif dengan metode penilaian terhadap laporan tahunan yang dikeluarkan oleh BNI Syariah tahun 2018-2019. Nilai pengungkapan CSR menggunakan indeks GRI pada tahun 2018 dari 43 item terdapat 7 item yang tidak terisi sehingga total skor yaitu 36 item. Kategori yang memiliki skor yang paling tinggi adalah kategori profil dan strategi organisasi dan Sosial. Sub-Kategori: Praktek Ketenagakerjan Dan Kenyamanan Bekerja dengan nilai yang sama yaitu 7, dan kategori lingkungan menempati skor yang paling rendah yaitu 3. Apabila dipersentasekan maka pengungkapan menggunakan indeks GRI memperoleh adalah 85\% apabila dikategorikan maka berada pada kategori sangat informatif. Sedangkan CSR tahun 2019 memiliki 9 item yang tidak terisi sehingga total skor yaitu 34 item. Kategori yang memiliki skor yang paling tinggi adalah kategori profil dan strategi organisasi dan Sosial. SubKategori: Praktek Ketenagakerjan Dan Kenyamanan Bekerja dengan nilai yang sama yaitu 7, dan kategori lingkungan menempati skor yang paling rendah yaitul. Apabila dipersentasekan maka pengungkapan menggunakan indeks GRI memperoleh adalah 79\% apabila dikategorikan maka berada pada kategori informatif.
\end{abstract}

Kata Kunci: CSR, Indeks ISR

This study aims to determine what is meant by CSR using the ISR index and to determine the implementation of CSR at BNI Syariah according to the ISR index. This research is a quantitative type of research with an assessment method of the annual reports issued by BNI Syariah 2018-2019. The value of CSR disclosure using the GRI index in 2018 from 43 items, 7 items were not filled so that the total score was 36 items. The category with the highest score was the category of organizational and social profiles and strategies. SubCategory: Employment Practices and Working Comfort with the same value, namely 7, and the environmental category has the lowest score, namely 3. If a percentage, the disclosure using the GRI index is $85 \%$ if categorized, it is in the very informative category. Meanwhile, CSR in 2019 has 9 unfilled items, so the total score is 34 items. The category with the highest score was the category of organizational and social profiles and strategies. SubCategory: Labor Practices and Working Convenience with the same score of 7, and the environmental category has the lowest score, namely 1 . If in percentage, the disclosure using the GRI index obtained is $79 \%$ if categorized, it is in the informative category.

Keywords: CSR, Index, ISR 


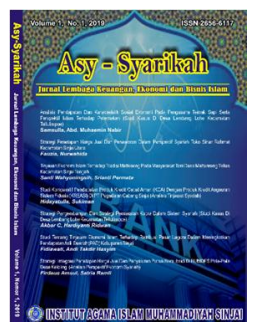

Asy-Syarikah

Jurnal Lembaga Keuangan, Ekonomi dan Bisnis Islam

Volume 3, No. 1, 2021

ISSN (print) : 2656-6117

ISSN (online) : 2715-0356

Homepage : http://journal.iaimsinjai.ac.id/index.php/asy-syarikah

\section{Pendahuluan}

Corporate Social Responsibility (CSR) merupakan wacana yang sedang mengemuka didunia perusahaan multinasional. Wacana ini digunakan oleh perusahaan dalam rangka mengambil peran menghadapi perekonomian menuju pasar bebas. Perkembangan pasar bebas yang telah membentuk ikatan-ikatan ekonomi dunia dengan terbentuknya $A S E A N$ Free Trade Area (AFTA), Asia-Pacific Economic Cooperation (APEC), dan sebagainya, telah mendorong perusahaan dari berbagai penjuru dunia untuk secara bersama melaksanakan aktivitasnya dalam rangka mensejahterakan masyarakat di sekitarnya CSR dapat didefinisikan sebagai segala upaya manajemen yang dijalankan entitas bisnis untuk mencapai tujuan pembangunan berkelanjutan berdasarkan pilar ekonomi, sosial dan lingkungan, dengan meminimumkan dampak negatif dan memaksimumkan dampak positif disetiap pilar. CSR merupakan sebuah konsep tanggung jawab sosial perusahaan, kini semakin diterima dengan luas. Perkembangan CSR di Indonesia(Yudho, 2018) telah mengalami peningkatan baik dalam kuantitas maupun kualitas dibandingkan dari tahuntahun sebelumnya. Hal ini terlihat dari semakin maraknya unit-unit bisnis yang melaporkan praktik $C S R$ dalam laporan keuangan tahunan. Pelaporan CSR merupakan praktik yang dibentuk berdasarkan nilai-nilai norma yang berlaku dimasyarakat. Pada sektor perbankan syariah, nilai-nilai norma yang digunakan adalah nilai-nilai agama Islam, atau disebut juga dengan nilai-nilai syariah.

Sejauh ini pengukuran CSR disclosure pada perbankan syariah masih mengacu kepada Global Reporting Initiative Index (Indeks GRI).(Yusuf, 2018) Padahal, terkait dengan adanya kebutuhan mengenai pengungkapan kinerja sosial diperbankan syariah, saat ini marak diperbincangkan mengenai Islamic Social Reporting Index (ISR). Indeks ISR merupakan tolok ukur pelaksanakaan kinerja sosial perbankan syariah yang berisi kompilasi item-item standar CSR yang ditetapkan oleh AAOIFI (Accounting and Auditing Organization for Islamic Financial Institutions) yang kemudian dikembangkan lebih lanjut oleh para peneliti mengenai item-item CSR yang seharusnya diungkapkan oleh suatu entitas Islam.(Sofyani, 2012)

Perbankan Syariah di Indonesia dalam pelaksanaan kegiatan tanggung jawab sosialnya masih banyak yang menggunakan pengukuran Global Reporting Initiative Index (Indeks GRI) dibanding mengunakan Islamic Social Reporting Index (ISR). Pada tahun 2010 kinerja tanggung jawab sosial perbankan syariah di Indonesia termasuk BNI Syariah dengan menggunakan Islamic Social Reporting Index (ISR) dengan angka 50\% dari penelitian sebelumnya yang dilaksanakan sesuai dengan index (ISR) hasil ini masih rendah dikarenakan hasil penelitian keseluruhan bank disyariah di Indonesia. Sehingga diperlukan penelitian lebih lanjut untuk mengungkap sejauh mana pelaksanaan (ISR) khusunya BNI Syariah dengan index (ISR).

\section{Metode}

Penelitian ini nantinya menelahaan dan memerikasa Annual Report BNI Syariah dan memperhatikan setiap item-item yang ada dan mennyusuaikan dengan item-item Indeks ISR. Penelitian ini dilaksanakan pada salah satu bank syariah yang ada di Indonesia melalui Website resmi BNI Syariah yang menjadi bahan penelitian yaitu data-data laporan keuangan BNI Syariah. Pada penelitian ini memfokuskan penelitiannya pada pelaksaan (ISR) BNI Syariah dengan Pelaksanaan (ISR) dengan merujuk sesuai index (ISR). Sumber data adalah semua keterangan yang diperoleh dari responden maupun yang berasal dari dokumen-dokumen baik dalam bentuk statistic atau dalam bentuk lainnya guna keperluan penelitian tersebut.(Joko Subagyo, 2006) Data yang dikumpulkan dalam penelitian ini adalah gambaran realitas hasil dan evaluasi kerja yang tertuang pada laporan 


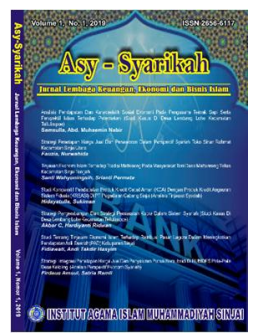

Asy-Syarikah

Jurnal Lembaga Keuangan, Ekonomi dan Bisnis Islam

Volume 3, No. 1, 2021

ISSN (print) : 2656-6117

ISSN (online) : 2715-0356

Homepage : http://journal.iaimsinjai.ac.id/index.php/asy-syarikah

tahunan,(Emzir, 2012) penulis mendownload Laporan Akhir Tahunan BNI Syariah. Tbk agar dapat mengumpulkan informasi pelaksanaan ISR dari Laporan Akhir tahun 2019 yang di download melalui website resmi BNI Syariah. Adapun langkah-langkah untuk menunjang analisis tersebut adalah sebagai berikut: Langkah pertama yaitu mengidentifikasi dan mengklarifikasi berbagai informasi yang terdapat dalam laporan tahunan BNI Syariah sesuai item-item ISR yang digunakan. Melakukan penelian (scoring) indeks ISR pada BNI Syariah Scoring dilakukan untuk mencari poin pengungkapan yang nilai dengan 1 jika terdapat sub-item yang diungkapkan dan 0 jika terdapat sub-item yang tidak diungkapkan dari item pengungkapan yang telah dijabarkan dalam tabel. Selanjutnya akan dilakukan analisis konten terhadap tiap-tiap tema indeks ISR pada BNI Syariah. Untuk mengetahui tingkat pengungkapan CSR Bank BNI Syariah. Selanjutnya dilakukan penilaian secara komulatif indeks. ISR pada BNI Syariah. Yang akan menentukan tingkat pengungkapan CSR BNI Syariah. Untuk memudahkan dalam mengetahui seberapa besar pengungkapan CSR di BNI Syariah Maka dilakukan rumus sebagai berikut:

Indek ISR $=$ Jumlah Poin yang diungkapkan X 100\%

Jumlah Skor Maksimal

Setelah melakukan penilaian (scoring) atas item-item indeks ISR, maka selanjutnya menentukan predikat tingkat pengungkapan CSR dari BNI Syariah. Dalam penilaian tingkat pengungkapan kinerja sosial BNI Syariah, dimana skor pengungkapan diklarifikasi dalam 4 predikat yaitu: Sangat Informatif (81\%-100\%), Informatif (66\%-80\%), Kurang Informatif $(51 \%-66 \%)$, dan Tidak Informatif $(0 \%-50 \%)$

\section{Hasil dan Pembahasan}

Hasil penelitian disajikan dalam bentuk grafik, tabel, atau deskriptif. Analisis dan interpretasi hasil ini diperlukan sebelum dibahas.

Corporate Social Responsibility (CSR) merupakan pengungkapan tanggung jawab sosial perusahaan yang sering juga disebut social disclosure, corporate social reporting, social accounting / corporate social responsibility merupakan proses komunikasi dampak sosial dan lingkungan dari kegiatan ekonomi organisasi terhadap kelompok khusus yang berkepentingan dan terhadap masyarakat secara keseluruhan. Pengertian corporate social reporting (CSR) menurut The World Bussiness Council on Sustaineble Development (WBCSD) yang merupakan lembaga internasional yang berdiri tahun 1995 dan beranggotakan lebih dari 120 perusahaan multinasional yang berasal dari 30 negara, menjelaskan CSR sebagai suatu komitmen dari perusahaan untuk dalam melaksanakan etika keperilakuan dan berkontribusi terhadap pembangunan ekonomi yang berkelanjutan. Komitmen lainnya adalah meningkatkan kualitas hidup karyawan dan keluarganya, komunitas lokal, serta masyarakat luas. CSR dapat pula didefinisikan sebagai tanggung jawab moral suatu perusahaan terhadap para strategi Stakeholdernya, terutama komunitas atau masyarakat disekitar wilayah kerja dan operasinya.

Konsep CSR dapat dilihat dari dua sudut pandang yang berbeda. Konsep pertama menyatakan bahwa tujuan perusahaan adalah mencari laba, sehingga CSR merupakan strategi dalam operasi bisnis. Sedangkan konsep yang kedua menyatakan bahwa tujuan perusahaan adalah mencari laba, mensejahterahkan orang dan menjamin keberlanjutan hidup tempat yang ditinggali. Global Compact Initiative (GCI) menyebut konsep ini dengan 3P yaitu: Profit (effetivity, efficiency, flexibility, and creativity), people (health, safety and welfare), dan Planet (environenta quality and disturbance) dimana gagasan tersebut menjadikan perusahaan tidak lagi dihadapkan pada tanggung jawab yang berpijak pada pada bottom line dimana nilai perusahaan direfleksikan melalui kondisi keuangannya saja. Perusahaan yang ingin terus melanjutkan oprasionalnya harus memperhatikan 3P 


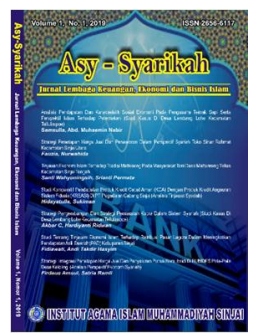

Asy-Syarikah

Jurnal Lembaga Keuangan, Ekonomi dan Bisnis Islam

Volume 3, No. 1, 2021

ISSN (print) : 2656-6117

ISSN (online) : 2715-0356

Homepage : http://journal.iaimsinjai.ac.id/index.php/asy-syarikah

(profit, people, planet). Selain mengejar profit atau keuntungan perusahaan juga harus memperhatikan dan terlibat pada pemenuhan kesejahteraan masyarakat (people) serta turut berkontribusi aktif dalam menjaga kelestarian lingkungan (planet).

Islamic Social Reporting (ISR) sangat dibutuhkan oleh masyarakat muslim dengan tujuan menampilkan akuntabilitas kepada Allah SWT dan masyarakat dan untuk meningkatkannya dengan memberikan informasi yang relevan untuk kebutuhan religius para pengambil keputusan Muslim. Pelaporan sosial dalam perspektif syariah yang berhubungan dengan pemahaman tentang akuntabilitas, keadilan sosial dan kepemilikan sosial. Akuntabilitas sangat dipengaruhi oleh konsep Tauhid, yang menegaskan bahwa segala sesuatu harus dipertanggungjawabkan kepada Allah SWT dan segala sesuatu yang dilakukan harus sesuai dengan perintah-Nya. Dalam konsep kepemilikan, Islam mengakui keberadaan individu, namun pada hakekatnya segala sesuatu adalah milik Allah SWT, pemilik bertanggung jawab menggunakan sumber daya yang dimoft sesuai perintah Allah SWT dan tujuan untuk rahmatan lilalamin (rahmat bagi seluruh alam).

Dengan menghitung pasar modal syariah, perusahaan yang termasuk dalam emiten syariah dimungkinkan menampilkan pula dimensi religius dalam pengungkapan laporan keuangannya. Pemangku kepentingan muslim mengharapkan perusahaan untuk mengungkapkan informasi lebih luas yang dapat membantu mereka Semua kebutuhan religius mereka (Othman dan Thani). Hal ini termasuk model pelaporan tanggung jawab sosial yang mengembangkan dalam indeks Tanggung Jawab Sosial Perusahaan (CSR) selama ini masih belum memenuhi informasi yang diperlukan dari perspektif syariah. Islamic Social Reporting Index merupakan sebuah standar alternatif yang digunakan untuk mengatur pelaporan tanggungjawab sosial perusahaan yang berbasis syariah. Islamic Social Reporting Index merupakan standar yang dikeluarkan oleh AAOIFI (Accounting and Auditing Organization for Islamic Financial Institution). (Awaliyah \& Vestari, 2018)

Pada CSR BNI Syariah pada tahun 2019 "Peningkatan kualitas pelaksanaan program tanggung jawab sosial perusahaan merupakan salah satu tujuan dari transformasi yang dijalankan BNI Syariah, yaitu untuk memberikan manfaat yang lebih besar kepada seluruh pemangku kepentingan. Berdasarkan laporan keuangan yang diterbitkan oleh BNI Syariah pada laman https://www.bnisyariah.co.id/ dapat kita ketahui bahwa pelaksanaan CSR telah dilakukan oleh BNI Syariah sejak tahun 2011 dengan kegiatan Manajemen Syukur BNI Syariah Malang yaitu BNI Syariah memberikan bantuan penunjang perpustakaan (buku-buku perpustakaan, almari buku); bantuan peralatan tulis menulis (buku dan tas) dan serta alat peraga pendidikan seperti peta dunia, bola dunia serta peraga edukasi lainnya. Tahun 2020 BNI Syariah masih tetap konsisten untuk melakukan kegiatan CSR dengan kegiatan BNI Syariah Peduli Korban Banjir Jabodetabek yaitu BNI Syariah bekerjasama dengan Yayasan Hasanah Titik (YHT) menyalurkan bantuan lebih dari 2000 paket sembako, selimut, makanan, obat-obatan, dan air bersih senilai total Rp 400 juta kepada korban banjir di beberapa titik di Jabodetabek.

Adanya konsep tanggung jawab sosial dalam Islam maka meningkatkan pula keinginan untuk membuat pelaporan ataupun pengungkapan sosial yang bersifat syariah. Hanya saja sampai saat ini belum ada standar pelaporan tanggung jawab sosial secara syariah yang bisa dijadikan patokan standar secara internasional. AAOIFI (Accounting and Auditing Organization for Islamic Financial Reporting) sebagai organisasi yang mengembangkan akuntansi dan auditing bagi lembaga keuangan syariah di tingkat keuangan syariah, akan tetapi standar AAOIFI tersebut tidak dapat dijadikan sebagai suatu standar atas pengungkapan tanggung jawab sosial secara syariah karena tidak menyebutkan keseluruhan item-item terkait pelaporan tanggung jawab sosial yang harus diungkapkan oleh perusahaan. Salah satu cara untuk menilai pelaporan tanggung jawab sosial 


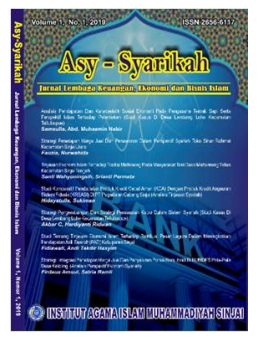

Asy-Syarikah

Jurnal Lembaga Keuangan, Ekonomi dan Bisnis Islam

Volume 3, No. 1, 2021

ISSN (print) : 2656-6117

ISSN (online) : 2715-0356

Homepage : http://journal.iaimsinjai.ac.id/index.php/asy-syarikah

perusahaan secara syariah yaitu dengan menggunakan indeks Islamic Social Reporting (ISR).

Menurut Haniffa, ISR adalah perpanjangan pelaporan sosial yang meliputi tidak hanya harapan dewan pengurus atas pandangan masyarakat terhadap peran perusahaan dalam ekonomi, tetapi juga memenuhi perspektif spiritual untuk pengguna laporan yang muslim. ISR bertujuan memdemonstrasikan akuntabilitas kepada Allah SWT dan komunitas.(Verawaty, 2016) ISR juga bertujuan meningkatkan transparasi dari aktivitas bisnis dengan menyediakan informasi yang relevan dalam memenuhi kebutuhan spiritual dari pengguna laporan perusahaan yang muslim. Selain itu, indeks ISR juga menekankan pada keadilan sosial terkait pelaporan mengenai lingkungan, kepentingan minoritas, dan karyawan. ISR sebenarnya merupakan kumpulan indeks pelaporan tanggung jawab sosial yang sudah ditetapkan oleh AAOFII yang sesuai dengan syariah.

Terdapat 52 total item yang dapat dijabarkan dalam indeks ISR apabila ditabulasikan maka penilaian dari item tersebut sebagai berikut:

Tabel Pengungkapan CSR Menggunakan Indeks ISR

\begin{tabular}{|c|c|c|c|}
\hline No & Kategori & 2018 & 2019 \\
\hline \multirow[t]{10}{*}{1.} & Pendanaan Dan Investasi & & \\
\hline & A. Riba & 1 & 1 \\
\hline & B. Gharar & 0 & 0 \\
\hline & C. Zakat & & \\
\hline & - Metode Yang Digunakan & 1 & 1 \\
\hline & - Jumlah Zakat & 1 & 1 \\
\hline & - Penerima Manfaat & 1 & 1 \\
\hline & $\begin{array}{l}\text { D. Kewajiban Atas Keterlambatan Pembayaran Piutang Dan } \\
\text { Penghapusan Piutang Tak Tertagih }\end{array}$ & 0 & 1 \\
\hline & E. Current Value Balance Sheet (CVBS) & 1 & 0 \\
\hline & F. Value Added Statement (VAS) & 0 & 0 \\
\hline \multirow[t]{5}{*}{2.} & Produk Dan Jasa & & \\
\hline & A. Produk Dan Jasa Yang Ramah Lingkungan & 0 & 0 \\
\hline & B. Status Kehalalan Produk & 0 & 0 \\
\hline & C. Kualitas Dan Keamanan Suatu Produk & 1 & 1 \\
\hline & D. Keluhan Konsumen & 1 & 1 \\
\hline \multirow[t]{12}{*}{3.} & Karyawan & & \\
\hline & A. Sifat Pekerjaan: & & \\
\hline & - Jam Kerja & 0 & 0 \\
\hline & - Liburan & 1 & 1 \\
\hline & - Manfaat Lain & 1 & 1 \\
\hline & B. Pendidikan Dan Pelatihan/Pengembangan SDM & 1 & 1 \\
\hline & C. Kesempatan Yang Sama & 1 & 1 \\
\hline & D. Keterlibatan Karyawan & 0 & 0 \\
\hline & E. Kesehatan Dan Keselamatan Kerja & 1 & 1 \\
\hline & F. Lingkungan Kerja & 1 & 1 \\
\hline & $\begin{array}{l}\text { G. Karyawan Khusus Kelompok Lain (Cacat, Mantan } \\
\text { Narapidana, Mantan Pecandu Narkoba) }\end{array}$ & 0 & 0 \\
\hline & $\begin{array}{l}\text { H. Eselon Yang Lebih Tinggi Di Perusahaan Melakukan Shalat } \\
\text { Berjamaah Dengan Para Manajer Tingkat Yang Lebih Rendah } \\
\text { Dan Menengah }\end{array}$ & 0 & 0 \\
\hline
\end{tabular}

Sumber: Data diolah Peneliti melalui pada laman https://www.bnisyariah.co.id/ 


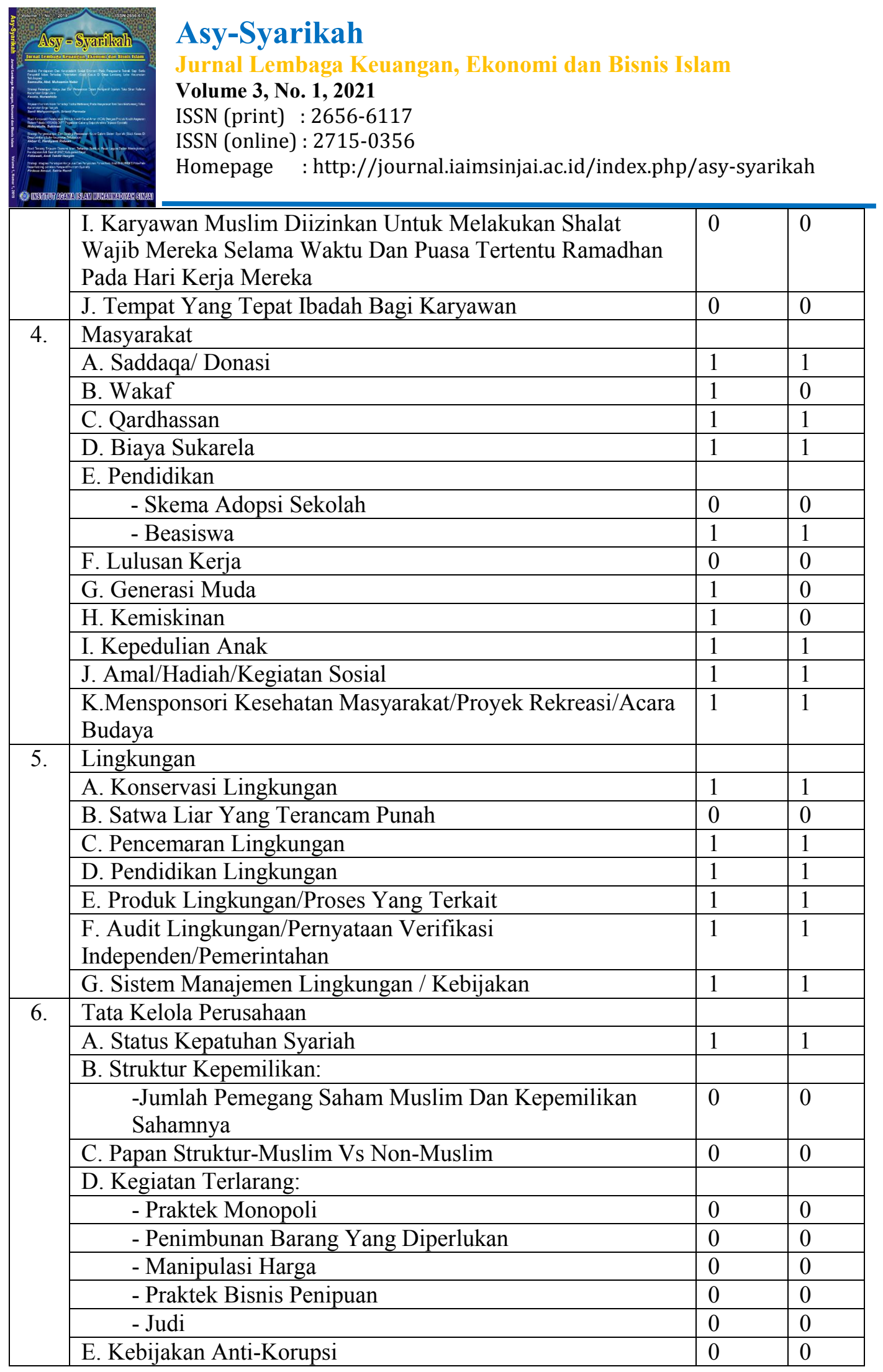

Pada tahun 2018 terdapat 22 item yang bernilai 0 atau dengan kata item tersebut tidak terdapat pengungkapannya pada laporan tahunan BNI Syariah tahun 2018. Kriteria yang memiliki nilai paling tinggi adalah masyarakat dengan nilai 10 sementara kriteria yang menempati nilai paling rendah adalah tata kelola perusahaan dengan nilai 1, apabila dipersenkan maka nilai yang diperoleh oleh laporan tahun 2018 adalah 57,69\% apabila dipersenkan maka berada pada kategori kurang informatif. 


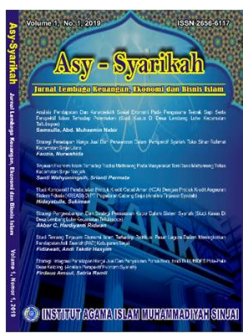

Asy-Syarikah

Jurnal Lembaga Keuangan, Ekonomi dan Bisnis Islam

Volume 3, No. 1, 2021

ISSN (print) : 2656-6117

ISSN (online) : 2715-0356

Homepage : http://journal.iaimsinjai.ac.id/index.php/asy-syarikah

Persentase nilai $:$ X/n X 100\%

$: 52 / 30 \times 100 \%=57,69 \%$

Keterangan:

$\mathrm{n} \quad$ : Jumlah kriteria pengungkapan Corporate Social Responsibility (CSR)

$\mathrm{X}$ : Poin bagi indikator yang dilaksanakan

Sedangkan pada tahun 2019 terdapat 25 item yang bernilai 0 . Kriteria yang memiliki nilai paling tinggi adalah masyarakat dengan nilai 7 sementara kriteria yang menempati nilai paling rendah adalah tata kelola perusahaan dengan nilai 1, apabila dipersenkan maka nilai yang diperoleh oleh laporan tahun 2019 adalah 52\% apabila dipersenkan maka berada pada kategori kurang informatif.

Pengelolaan CSR BNI Syariah melalui Yayasan Hasanah Titik yang merupakan yayasan yang diberikan amanah oleh BNI Syariah dalam menerima, mengelola, maupun menyalurkan ZISWAF perusahaan, pegawai, maupun masyarakat kepada pihak-pihak yang membutuhkan dan termasuk dalam delapan asnaf, yaitu fakir, miskin, amil, mualaf, riqab (hamba sahaya), gharim (orang yang terlilit utang), fisabilillah, dan ibnu sabil (orang yang sedang dalam perjalanan). Pada Mei 2014, UPZ BAZNAS berubah badan hukum menjadi Yayasan Hasanah Titik yang juga bertangggungjawab terhadap pengelolaan program CSR BNI Syariah. YHT dikelola oleh SDM yang mempunyai kapabilitas dan serta kapasitas di bidangnya. Untuk menjaga transparansi dan kredibilitasnya, sejak tahun 2015 YHT menggunakan jasa auditor independen untuk menilai kinerja keuangan dan kinerja ketepatan penyaluran program sosial yang menggunakan dana zakat. Hingga tahun 2018, YHT selalu memperoleh opini wajar dalam semua hal material. Teknik analisis yang penulis gunakan untuk mengetahui nilai persentase pengungkapan CSR di BNI Syariah jika dilihat berdasarkan Global Reporting Initiative (GRI) Index adalah dengan menggunakan standar GRI G4 tahun 2016. GRI (G4) ini kemudian penulis pilih elemen-elemennya yang terkait dengan kinerja industri perbankan. Apabila sudah diungkapkan secara penuh, maka nilai maksimal yang dapat dicapai adalah 43. Apabila ditabulasikan indeks-indeks tersebut sebagai berikut:

Tabel Pengungkapan CSR Menggunakan Indeks GRI

\begin{tabular}{|c|c|c|c|c|}
\hline No & Kategori & Aspek & 2018 & 2019 \\
\hline \multirow[t]{7}{*}{1.} & \multirow{7}{*}{$\begin{array}{c}\text { Profil Dan Strategi } \\
\text { Organisasi }\end{array}$} & Strategis dan Analisis & 1 & 1 \\
\hline & & Profil & 1 & 1 \\
\hline & & $\begin{array}{c}\text { Identifikasi Aspek Material dan } \\
\text { Boundary }\end{array}$ & 1 & 1 \\
\hline & & Keterlibatan Pemangku Kepentingan & 1 & 1 \\
\hline & & Profil Laporan & 1 & 1 \\
\hline & & Tata Kelola & 1 & 1 \\
\hline & & Etika dan Integritas & 1 & 1 \\
\hline \multirow[t]{4}{*}{2.} & \multirow[t]{4}{*}{ Ekonomi } & Kinerja Ekonomi & 1 & 1 \\
\hline & & Keberadaan di Pasar & 1 & 1 \\
\hline & & Dampak Ekonomi Tidak Langsung & 1 & 1 \\
\hline & & Praktik Pengadaan & 1 & 1 \\
\hline \multirow[t]{3}{*}{3.} & \multirow[t]{3}{*}{ Lingkungan } & Energi & 1 & 1 \\
\hline & & Air & 1 & 0 \\
\hline & & Emisi & 1 & 0 \\
\hline \multirow{3}{*}{ a. } & \multirow{3}{*}{$\begin{array}{c}\text { Sosial. Sub- } \\
\text { Kategori: Praktek } \\
\text { Ketenagakerian Dan }\end{array}$} & Kepegawaian & 1 & 1 \\
\hline & & Hubungan Industrial & 1 & 1 \\
\hline & & Kesehatan dan Keselamatan Kerja & 1 & 1 \\
\hline
\end{tabular}




\begin{tabular}{|c|c|c|c|c|}
\hline 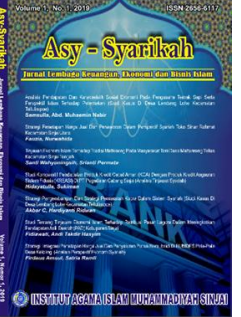 & \multicolumn{4}{|c|}{$\begin{array}{l}\text { Asy-Syarikah } \\
\text { Jurnal Lembaga Keuangan, Ekonomi dan Bisnis Islam } \\
\text { Volume 3, No. 1, 2021 } \\
\text { ISSN (print) : 2656-6117 } \\
\text { ISSN (online) : 2715-0356 } \\
\text { Homepage : http://journal.iaimsinjai.ac.id/index.php/asy-syarikah }\end{array}$} \\
\hline & \multirow{4}{*}{$\begin{array}{l}\text { Kenyamanan } \\
\text { Bekerja }\end{array}$} & Pelatihan dan pendidikan & 1 & 1 \\
\hline & & $\begin{array}{c}\text { Keberagaman dan Kesetaraan } \\
\text { Peluang }\end{array}$ & 1 & 1 \\
\hline & & $\begin{array}{c}\text { Kesetaraan Remunasi Perempuan } \\
\text { dan Lakilaki }\end{array}$ & 1 & 1 \\
\hline & & $\begin{array}{c}\text { Asesmen Pemasok Terkait } \\
\text { Ketenagakerjaan }\end{array}$ & 1 & 1 \\
\hline \multirow[t]{10}{*}{ b. } & \multirow{10}{*}{$\begin{array}{c}\text { Sosial. Sub- } \\
\text { Kategori: Hak Asasi } \\
\text { Manusia }\end{array}$} & Investasi & 1 & 1 \\
\hline & & Non-diskriminasi & 1 & 1 \\
\hline & & $\begin{array}{c}\text { Kebebasan Berserikat dan Perjanjian } \\
\text { Kerjasama }\end{array}$ & 1 & 1 \\
\hline & & Pekerja Anak & 1 & 1 \\
\hline & & Pekerja Paksa atau Wajib Kerja & 0 & 0 \\
\hline & & Praktik Pengamanan & 1 & 1 \\
\hline & & Hak Adat & 0 & 0 \\
\hline & & Asesmen & 0 & 0 \\
\hline & & Asesmen Pemasok dan HAM & 0 & 0 \\
\hline & & Mekanisme Pengaduan HAM & 1 & 1 \\
\hline \multirow[t]{7}{*}{ c. } & \multirow{7}{*}{$\begin{array}{l}\text { Sosial. Sub- } \\
\text { Kategori: } \\
\text { Masyarakat }\end{array}$} & Masyarakat Lokal & 1 & 1 \\
\hline & & Anti Korupsi & 0 & 0 \\
\hline & & Kebijakan Publik & 1 & 1 \\
\hline & & Anti Persaingan & 0 & 0 \\
\hline & & Kepatuhan & 1 & 1 \\
\hline & & $\begin{array}{c}\text { Asesmen Pemasok Atas Dampak } \\
\text { Terhadap Masyarakat }\end{array}$ & 0 & 0 \\
\hline & & $\begin{array}{c}\text { Mekanisme Pengaduan Terhadap } \\
\text { Masyarakat }\end{array}$ & 1 & 1 \\
\hline \multirow[t]{5}{*}{ d. } & \multirow{5}{*}{$\begin{array}{l}\text { Sosial. Sub- } \\
\text { Kategori: } \\
\text { Tanggungjawab } \\
\text { Atas Produk }\end{array}$} & Kesehatan Keselamatan Pelanggan & 1 & 1 \\
\hline & & Pelebelan Produk dan Jasa & 1 & 1 \\
\hline & & Komunikasi Pemasaran & 1 & 1 \\
\hline & & Privasi Pelanggan & 1 & 1 \\
\hline & & Kepatuhan & 1 & 1 \\
\hline
\end{tabular}

Sumber: Data diolah Peneliti melalui pada laman https://www.bnisyariah.co.id/

Berdasarkan tabel diatas dapat diketahui bahwa nilai pengungkapan pada tahun 2018 dari 43 item terdapat 7 item yang tidak terisi sehingga total skor yaitu 36 item. Kategori yang memiliki skor yang paling tinggi adalah kategori profil dan strategi organisasi dan Sosial. Sub-Kategori: Praktek Ketenagakerjan Dan Kenyamanan Bekerja dengan nilai yang sama yaitu 7, dan kategori lingkungan menempati skor yang paling rendah yaitu 3. Apabila dipersentasekan maka pengungkapan menggunakan indeks GRI memperoleh adalah 85\% apabila dikategorikan maka berada pada kategori sangat informatif. Sedangkan CSR tahun 2019 memiliki 9 item yang tidak terisi sehingga total skor yaitu 34 item. Kategori yang memiliki skor yang paling tinggi adalah kategori profil dan strategi organisasi dan Sosial. Sub-Kategori: Praktek Ketenagakerjan Dan Kenyamanan Bekerja dengan nilai yang sama yaitu 7, dan kategori lingkungan menempati skor yang paling rendah yaitu 1. Apabila dipersentasekan maka pengungkapan menggunakan indeks GRI memperoleh adalah 79\% apabila dikategorikan maka berada pada kategori informatif. 


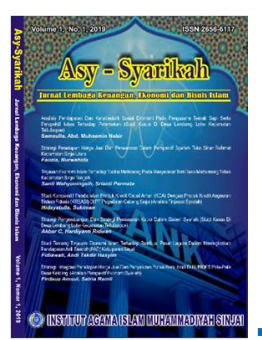

Asy-Syarikah

Jurnal Lembaga Keuangan, Ekonomi dan Bisnis Islam

Volume 3, No. 1, 2021

ISSN (print) : 2656-6117

ISSN (online) : 2715-0356

Homepage : http://journal.iaimsinjai.ac.id/index.php/asy-syarikah

\section{Simpulan}

Pada tahun 2018 terdapat 22 item yang bernilai 0 atau dengan kata item tersebut tidak terdapat pengungkapannya pada laporan tahunan BNI Syariah tahun 2018. Kriteria yang memiliki nilai paling tinggi adalah masyarakat dengan nilai 10 sementara kriteria yang menempati nilai paling rendah adalah tata kelola perusahaan dengan nilai 1, apabila dipersenkan maka nilai yang diperoleh oleh laporan tahun 2018 adalah 57,69\% apabila dipersenkan maka berada pada kategori kurang informatif. Sedangkan pada tahun 2019 terdapat 25 item yang bernilai 0 . Kriteria yang memiliki nilai paling tinggi adalah masyarakat dengan nilai 7 sementara kriteria yang menempati nilai paling rendah adalah tata kelola perusahaan dengan nilai 1, apabila dipersenkan maka nilai yang diperoleh oleh laporan tahun 2019 adalah 52\% apabila dipersenkan maka berada pada kategori kurang informative.

Nilai pengungkapan CSR menggunakan indeks GRI pada tahun 2018 dari 43 item terdapat 7 item yang tidak terisi sehingga total skor yaitu 36 item. Kategori yang memiliki skor yang paling tinggi adalah kategori profil dan strategi organisasi dan Sosial. SubKategori: Praktek Ketenagakerjan Dan Kenyamanan Bekerja dengan nilai yang sama yaitu 7, dan kategori lingkungan menempati skor yang paling rendah yaitu 3. Apabila dipersentasekan maka pengungkapan menggunakan indeks GRI memperoleh adalah $85 \%$ apabila dikategorikan maka berada pada kategori sangat informatif. Sedangkan CSR tahun 2019 memiliki 9 item yang tidak terisi sehingga total skor yaitu 34 item. Kategori yang memiliki skor yang paling tinggi adalah kategori profil dan strategi organisasi dan Sosial. Sub-Kategori: Praktek Ketenagakerjan Dan Kenyamanan Bekerja dengan nilai yang sama yaitu 7, dan kategori lingkungan menempati skor yang paling rendah yaitu1. Apabila dipersentasekan maka pengungkapan menggunakan indeks GRI memperoleh adalah 79\% apabila dikategorikan maka berada pada kategori informative. 


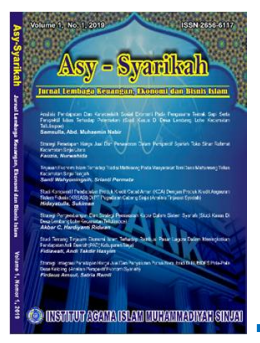

Asy-Syarikah

Jurnal Lembaga Keuangan, Ekonomi dan Bisnis Islam

Volume 3, No. 1, 2021

ISSN (print) : 2656-6117

ISSN (online) : 2715-0356

Homepage : http://journal.iaimsinjai.ac.id/index.php/asy-syarikah

\section{Daftar Pustaka}

Awaliyah, M., \& Vestari, M. (2018). Analisis Pengungkapan Corporate Social Responsibility Perbankan Syariah Di Indonesia. Magisma: Jurnal Ilmiah Ekonomi Dan Bisnis, 6(2), 52-66. https://doi.org/10.35829/magisma.v6i2.34

Emzir. (2012). Metode Penelitian Kualitatif Analisis Data (Rajagrafin).

Joko Subagyo. (2006). Metode Penelitian(Dalam Teori Praktek). Rineka cipta.

Sofyani, H. (2012). Islamic Sosial Reporting Index Sebagai Pengukuran Kinerja Sosial Perbankan Syariah. Studi Akuntansi, 4, no. 1.

Verawaty, C. I. M. D. (2016). Analisis Komparasi Indeks Islamic Social Reporting Perusahaan Perbankan Syariah Dan Perusahaan Go Publik Yang Listing Di Jakarta Islamic Index. Akuisisi, Citra Inda.

Yudho, K. F. dan P. (2018). Analisis Pengungkapan Tanggung Jawab Sosial Perbankan Syariah di Indonesia Berdasarkan Islamic Sosial Reperting Index. Universitas Negeri Semarang”. Jurnal 5.

Yusuf, Y. (2018). Islamic Corporate Social Responsibility (I-CSR). 